\title{
Pocket-sized help for people with dementia
}

$\mathrm{L}$

ife started going haywire for James McKillop in his late 50s. He began making mistakes at his job with the Scottish government. He began making mistakes on the road while driving. When he took a bus, the driver would sometimes tell him he paid too much for his fare.

At age 59, McKillop, a retired civil servant from Glascow, Scotland, finally found out what the problem was. He was diagnosed with multi-infarct dementia, sometimes called vascular dementia, which is the most common form of dementia after Alzheimer disease. Now that he knew the problem, he had to set about living with it.

At first it wasn't easy, especially when he went shopping. "I couldn't remember the names of things or count money," says McKillop, who is now 69. "But if people can't see a crutch or a missing limb, they think there is nothing wrong with you."

His struggles in stores led to poor treatment from clerks and raised eyebrows from other customers, so in 2001, McKillop invented a simple yet effective means of letting people know he had a problem: the "Dementia Helpcard." It's the size of a credit card and states that the bearer has an illness called dementia and would appreciate assistance and understanding.

"I wanted a discreet way to let people know I was having problems," says McKillop. "I thought a small card would work quite well."

In an email, McKillop described what used to be a typical shopping experience for him before he thought of the help card: "I would hand over what I thought was the correct amount. The assistant would look at the coins and state the price again and I would hand over more money, which wasn't obvi-

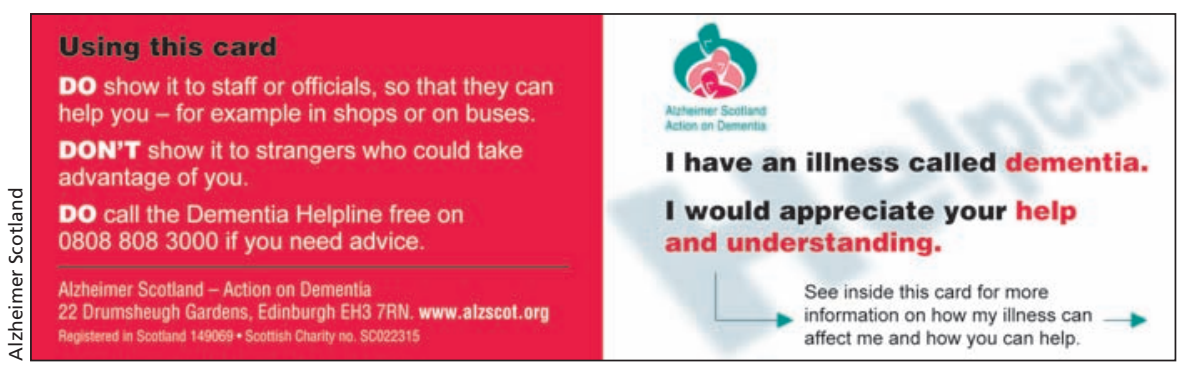

"When people read something they pay more attention," says dementia help card developer James McKillop. "A card looks a wee bit more official."

ously enough. Then they would say in an exasperated tone, the price once again. I would end up holding out a handful of change and ask them to take the correct money."

"This would make them suspicious and they would look askance at me, as if they had never heard of an adult who can't count money and look around as if for a hidden camera, in case they were being filmed. I would then be forced to say I couldn't count money and unbelieving, they would ask me to repeat what I said. So I would end up near shouting."

With the card, those experiences became a thing of the past. People who were once suspicious became anxious to help. He was no longer looked down on, but instead treated like someone with a problem over which he had little control. "When people read something they pay more attention," says McKillop. "A card looks a wee bit more official."

Alzheimer Scotland adopted the Dementia Helpcard soon after McKillop invented it and made it available to anyone who wanted one. It has since undergone slight design changes but remains mostly the same. At the suggestion of the Scottish Dementia Working Group, the National Health Service for Scotland included the card in every copy of the new version of a booklet distributed to people who receive dementia diagnoses. Other countries, including Sweden, have also begun using the card.

"When we have information stands at conferences, we find they are very popular with health and social care professionals, who take them to pass onto patients/clients and their carers," Maureen Thom, information manager for Alzheimer Scotland, writes in an email.

As for McKillop, he has become a vocal advocate for the rights of people with dementia, often travelling and delivering presentations that he calls "messages of hope." People with dementia must carry on with their lives, he says, even if learning new things takes three times as long as it used to. Sure, he misses certain things - particularly driving, which he hasn't done in seven years - but he tells people that his quality of life is still great, and that no person with dementia should feel condemned to a life of house-bound idleness.

"You make the best of what you've got. You concentrate on what you can do and live your life accordingly," he says. "Most of my friends are in graveyards. If they could trade that to have the life I have, they would." - Roger Collier, CMAJ

CMAJ 2011. DOI:10.1503/cmaj.109-3705 